Historic, Archive Document

Do not assume content reflects current scientific knowledge, policies, or practices. 


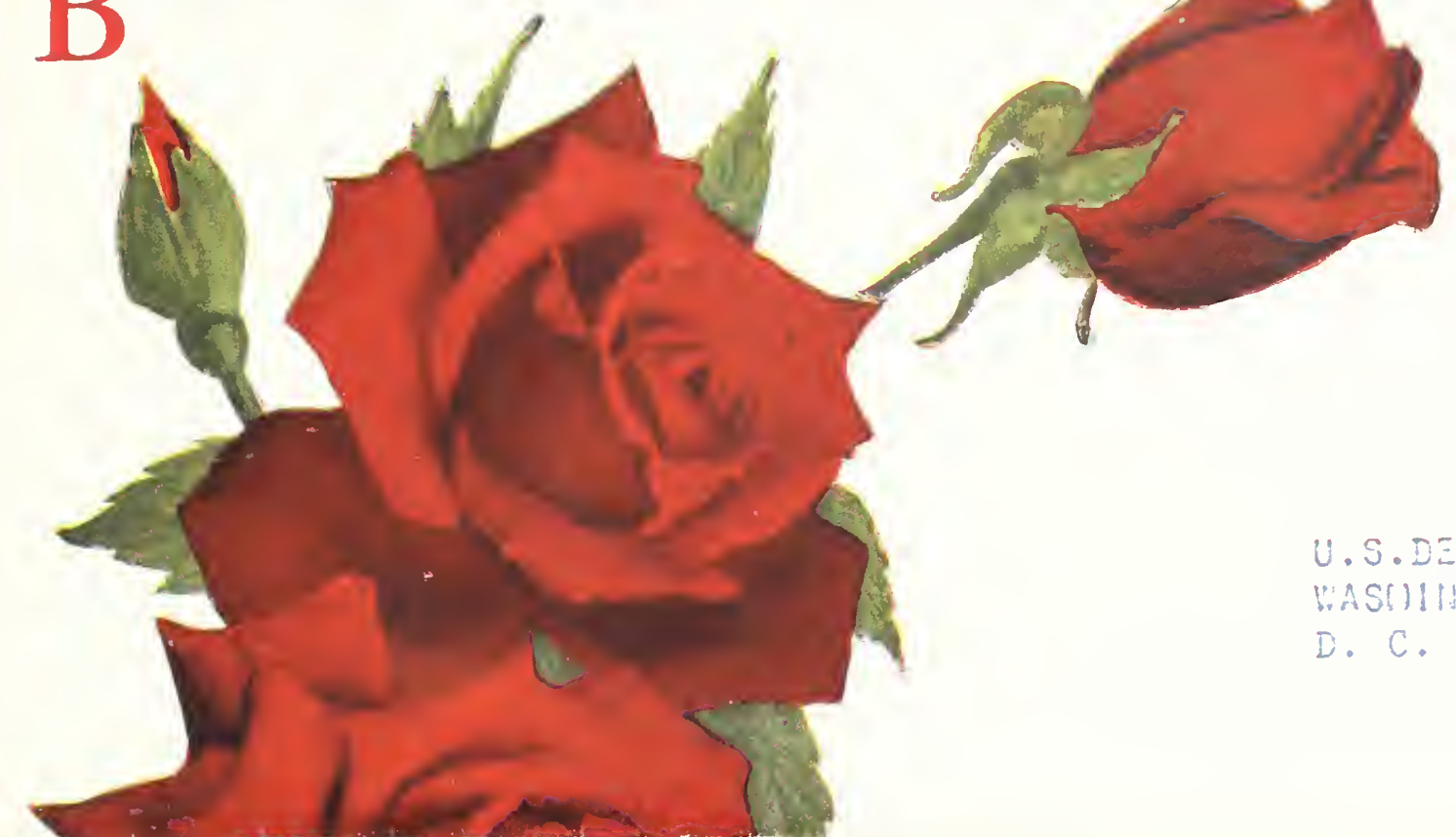

MARVELOUS BARGAINS IN ROSES, MUMS, CANNAS, CARNATIONS

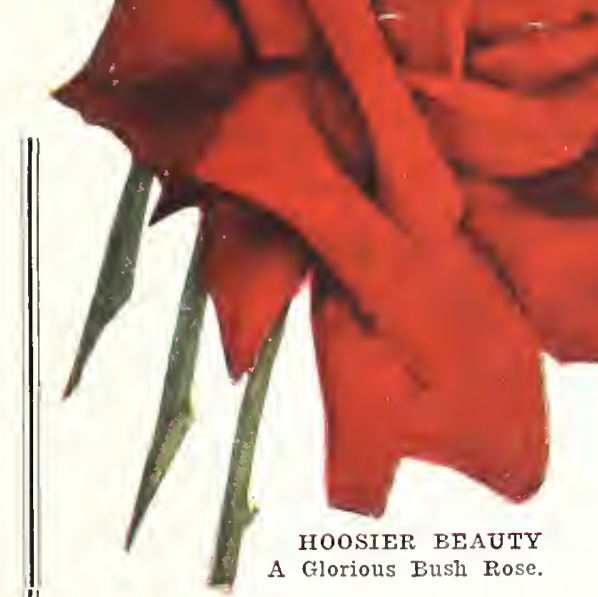

\section{6 "Hoosier"}

\section{Collection Garden} Roses $\mathrm{T} 2.00$ Cream of our stock. Ten for N 2 Postp'd Here are the ten most superb garden Roses now known. They will thrive in all sections and produce their splendid flowers in the greatest of abundance contimuasly this year. The have consideled everything in the selection-hari-

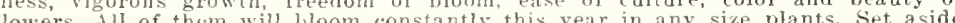
al misgivings and plant this "HOOSILR cOLLECIION." You will find the 垈 as to meet the recuirements of every pulse. Wach variety labeled and safe ar. rival fuaranteed to any point in the United States.

HOOSIER BEAUTY-The most beau-

tiful erimson bush rose now know

size, of a velvety crimson color.

ALEXANDER HILL GRAY-The S1-

prene yellow garden rose. The lest

pers, deep lemon sellow

Medal variety

PINK COCHET-CThe great pink gar.

bloom.

AMELIA GUDE-New and beatiful. low, petals tipped with lighter shades. JEANNETTE HELLER-One of the

greatest garren roses in the wolld, exruisite
shades.

PREMTER - I wonderful Hybrit Tea Rose. leep rose pink, perfect form and contimuously blooming.

COLUMBIA - Deep peach pink, mag nifient flowers, immense in size firden rose, aluzost thorules. an

MRS. B. R. CANT-One of the best if uot the hest exprblooming lush Rose of its color. strong growing, hardy. Produces during the season hindred of deеp crimson-pink flowers rose WHTE MAMAN cOCHET-Super flowers colon" white; a wonderful gar KAXSERIN AUGUSTA VICTORIAWhite, greatest of all white Hybrin Tea bush Roses. Cont

Special Offer This entire collection of ten magnificent Heller Roses, the entire sot, extra heavy, first size plants for $\$ 2.00$, postpaid by mail all charges paid, for $\$ 7.50$; the entire set of ten varieties in immense Star size plants, prepaid by parcel post for $\$ 12.00$. All on their own roots. gEORDER AS 'HOOSIER COLLECTION.'

\section{Hardy Cochet Roses}

The Cochet Roses are among the greatest of harig everbloming Roses. matter where you live, they are hardy, thriving vigorously and blooming witi last for years. The tlowers are superl. The Cochet. hoses berause of their wun. derful merit, are a specialt

WHITE MAMAN COCHET-In shape and size like its narent, the Pink Cochet. but of a. snowy Write, occasionaliy th
white Roses for open-ground culture.

RED MAMAN COCHET-t rreat red Rose and produces magnificent flower. in wonclerful profusion on long. strong stem.

YELLOW MAMAN COCHET-In shape size nnd suljstance this is a tyoical Cochet Rose except that it is of a depp, golich

PINK MAMAN COCHET-Long considered the Queen of all Pink Farden Roses,

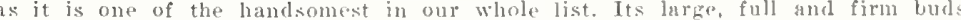
show wonderful depth and richness of color as they open into very large, per fectly double flowers of splondid sustance on long stiff stems. A clear, ricl dependable Rose.

CRIMSON MAMAN COCHET-This is without dould one of the sweetest and best hardy Hylurid Tea lioses of its class and color. The plant crows to a strolle sturdy himsh. and liears immense qua

First size, magnificent plants of any of the Cochet Roses, 25c; each; any parcel post. The demand for these wouderful Cochet Boses is ellormous.

Special Offer One each of this famous Cochet Rose Set, first size plants, two-year-old plants, prepaid by parcel post, $\$ 4.00$.

We Stake Our Reputation on the Merits of 'These Gireat $\mathrm{C}$ (Is lections. They Will Produce Hundreds of Flowers This Vear

Terms: CASH WITH ORDER. Personal Check, Postoffice Money Order, sent at our risk. Stamps accepted in small auounts ONLY. 


\section{Jeannette Heller Special Collection of Roses}

Fiere is a great collection of best Roses for general culture. In our vast collection the best garden Roses for all sections of the country. Hardiness, vigorous growth, freedom of bloom, color and beauty of flower, make them a most desirable collection for amateur plant ing. They will bloom with the utmost freedom this year, and all are bush Roses except the great pauls sclarlet, a climber, which comes into bloom the second Jear. No two alike. In this collection we include our magnificent Jeannette Heller, The one best garden Rose in
America. All labeled. Safe arrival guaranteed to any point in the United States proper.

\section{TEN BEAUTIFUL HELLER ROSES POSTPAID FOR $\$ 1.75$.}

JEANNETTE HFILER. An exquisite blending of pink and creal

VICTOR. Beautiful, large full flowers of great depth and richness; produced on long, stiff stems.

MRS. B. R. CANT. Handsome crimson pink kose of fine form and
hardy and everblooming.

GRUSS AN TEPIITZ. One of the most brilRose.

RAISERIN AUGUSTA VICTORIA. The handsomest of all cream white Roses. Very lardy and constantly in bloom.

PAUL'S SCARLIT CLIMBER. Produced in immense chusters. Jlaning scarlet.
orous climber, hardy everywhere.

ETOILE DE IYON. Strong growing, healthy and wonderfully free blooming. Magnificent gold en yellow.

PRINCE E. C. D'AFEIFBERG. Vigorous as at oak. Superty formed flowers, bright scarlet, Fiose.

BRIDESMaID. A most beautiful, fragrant pinl Rose. A splendid grower. Massive flowers on shell pink. Superb.

THE BRIDE. tion. A queen among white Roses. Sus

Special Offer This magnificent collection, 10 in all, in strong, first size plants, $\$ 1.75$, pre-

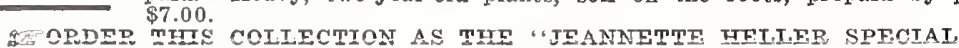

\section{Famous Jeannette Heller Rose}

The Best, Strongest, Healthiest, Hardiest, Biggest Selling and Most Beautiful Busl Rose in the World. A Rose that grows anywhere under all conditions, blooms abundantly and produces its the best bush Rose in the world. That's "JIAANNICTri has earned the right to be telmed is the healthiest growing Rose now in existence, growing luxuriantly everywhere. Perfetly formed flowers; indescribable in colol, ranging from shell pink, sometimes rumms from rosy blush to yellow and sometimes almost pearly white, immense in size and magnificent in form. Produced continuously. Wonderful in growth with the vigor of an oak Practicit glows where , needs no petting, grows it glows where weeds grow, in any soil or climate. An

want it! You will become a Rose enthusiast the rest of your life. That is the reason ve want you to try a few plants of "JEANNETTE HELLER"

Price: All sizes postpaid by parcel post. Strong, first size plants, 30c each; 4 for $\$ 1.00$; $\$ 2.50$ per dozen. Large, two-year-old plants, soil on roots, $\$ 1.00$ each, $\$ 10.00$ per dozen. Sta size, $\$ 1.50$ each; $\$ 12.00$ per dozen. All prices include parcel post charges.

"I purehased a star. size Jeannette Heller from you. Its growth this season has been wollderful.
It lias bloomed constantly since June, and now las over two dozen nice buds on it. Today I cut
three of the most beautiful roses I ever saw from it. I have ten roses of the best I could pur-
ehase. I would not give 'Jeannette Heller' for all the other ten eombined." - M. M. Moser, Ham-
ilton, Ohio.
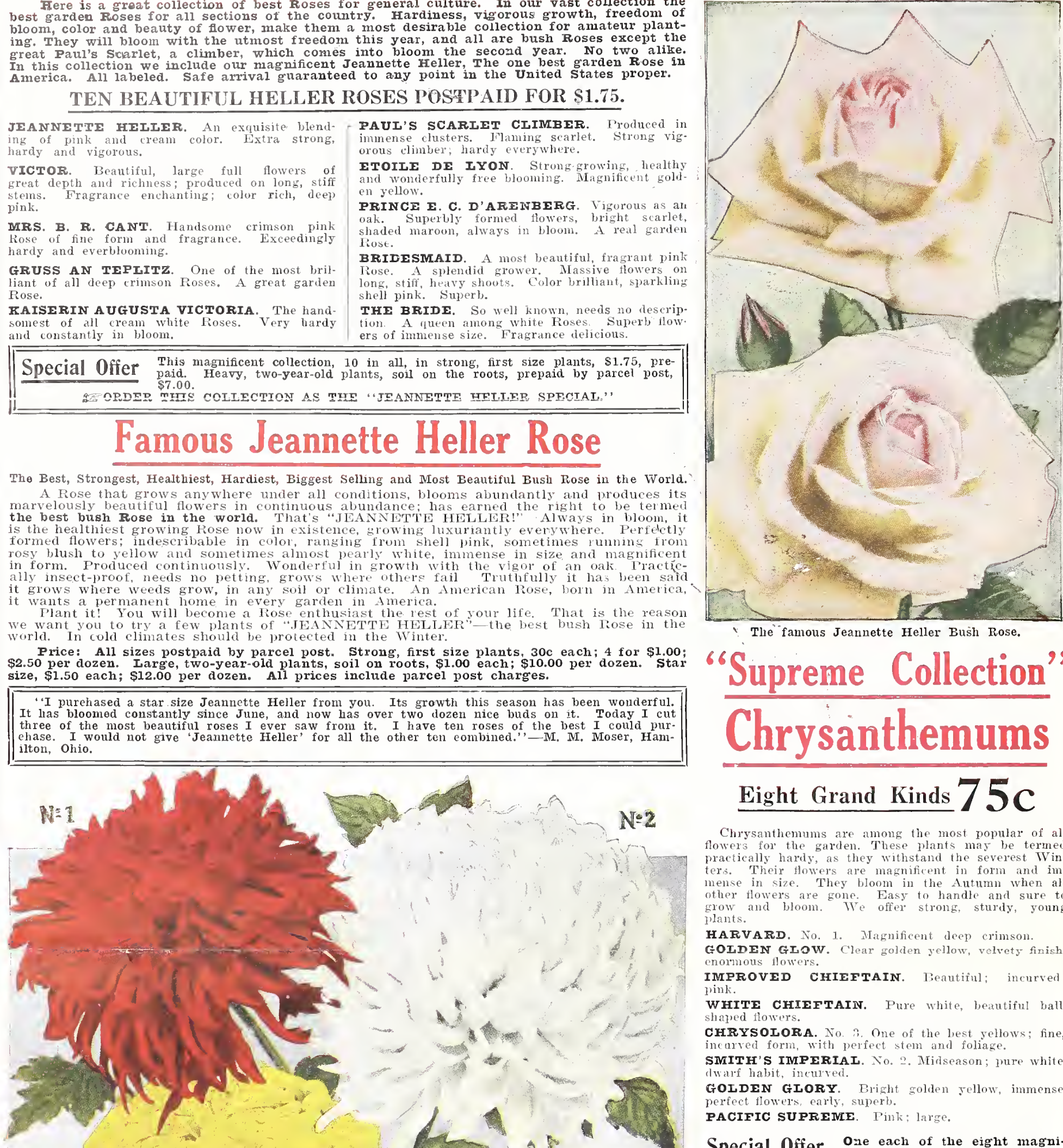

¿The" famous Jeannette Heller Bush Rose.

"S Supr "Supreme Collection"

\section{Eight Grand Kinds 75c}

Chrysanthemums are among the most popular of all flower's for the garden. These plants may be termed practically hardy, as they withstand the severest Winters. Their flowers are magnificent in form and immense in size. They bloom in the Autumn when all grow and bloom. We offer strong, sturdy, young

HARVARD. No, 1, Nagnificent deep crimson.

GOLDEN GIOW. Clear golden yellow, velvety finish, IMPROVED CHIEFTAIN. Beautiful; incurved WhIte chisftaris. Pure white, beatiful ball-

SOLORA. No ? One of the lest yellows; fine, SMITH'S IMPERIAL. No. 2. Midseason; pure white, GOLDEN GLORY. Bright golden rellow, immense, perfect flowers, early, superb.
PACIFIC SUPREME. Pink: large.

Special Offer One each of the eight magnifrent "Mums" for $75 \mathrm{c}$.
prescibed above, TLEASE ORDER-AS “SUPREME COLIBOTION',

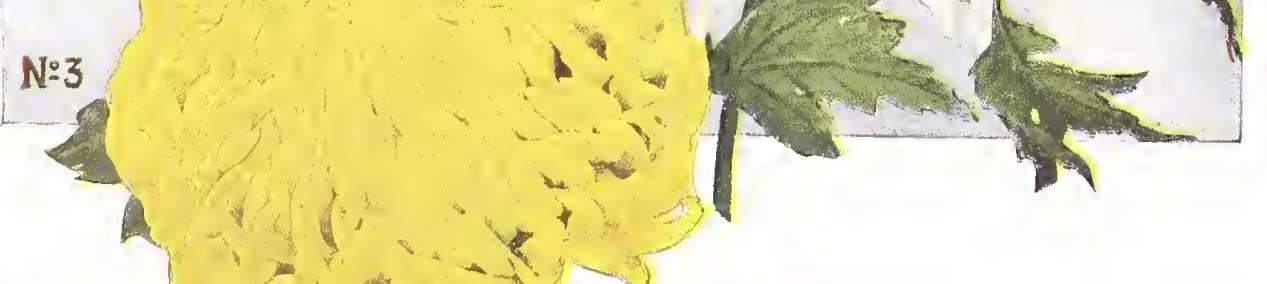
'Baby' Set of 'Mums'

\section{Four for 50c}

Extremely lardy, each plant producing thousanis
extreme. Excellent for cutting. Last until frost cuts KLONDIKE. Gorgeous bronze-yellow. MRS. BUCKINGHAM. Single, rosy pink.

Special Offer one each of the above four Pompon "Mums", for 50e, prepaid.
, perfectly double flowers. Showy in the

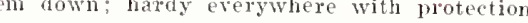

FAIRY QUEEN. Rose-pink 


\section{"ColumbiaSet" of Roses \\ Five Beautiful Roses, Postpaid.}

Favorite Collection $\$ 1$

COLUMBIA-Magnificent, large, fu?] VICTOR Beautiful, large full flower and double silvery pink flowers. Frag. of great depth and rith

rant as the American Beauty.

KAISERIN AUGUSTA VICTORIA

The handsomest of all cleam whit

Roses
bloom

Five splendid, hardy, everblooming kinds, $\$ 1.00$ prepaid by parcel post. Two-year-old pot grown plants, 5 for $\$ 1.00$, postpaid.

\section{Complete Family Flower Garden}

Ten Assorted

Flowers, best va-
rieties, prepaid

1 Rose, Climbing American Beauty-A per.

1 Bush Rose, Columbia-Hybrid Tea

1 Tuberose Excelsior Pearl-Flowers pure

White, ver'y douh

1 Canna, Wintzer's Colossal

1 Chrysanthemum, Unaka-One of the best va-

1 Iris-Hardy everywhere and permanent, grow-

1 Boston Fern- Long, broad fronds, drooping

For $\$ 1.00$ we will send this great collection de

scribed above-A complete family flower garden scribed above-A
for $\$ 1.00$, prepaid.

\section{"Baby Doll"' Set of Roses \\ Six Roses, Postpaid $\varphi$}

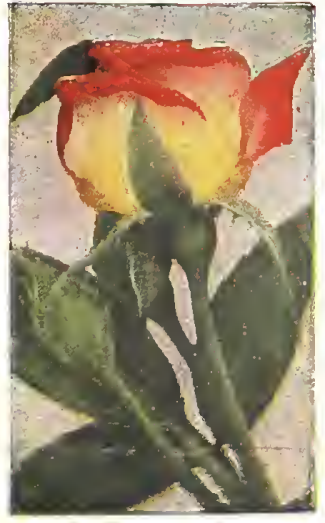

Dainty Baby Doll

\section{BABY DOLL}

old gold: always

THE BRIDE

nense size. Fragranco delicious.

MRS. B. R. CANT-Handsome crimson pink Ros of fine form and fragrance. Exceedingly harly and

PINK COCHET-The reat pink garden Rose.

PIN coctom.

ETOILE DE LYON-Strong-growing, healthy and

vellow.

PRINCE E. C. D'ARENBERG - Vigorous as an oa

coon, always in bloom. A real garden Rose.

Six splendid, hardy, everblooming kinds, $\$ 1.00$ prepaid by parcel post. Two

\section{Bargains in Cannas}

We have a fine collection of these imposing foliage ntants in noveltirs and

Canna Bed No. 27| Canna Bed No. 28

FOR BED 7 FEET ACROSS

1 Scarlet with red foliage for center.

6 Yellow for first cirele.

FOR BED 10 FEET ACROSS

Yed foliaga for center.

12 Pink for second circle.

12 Red for second circle

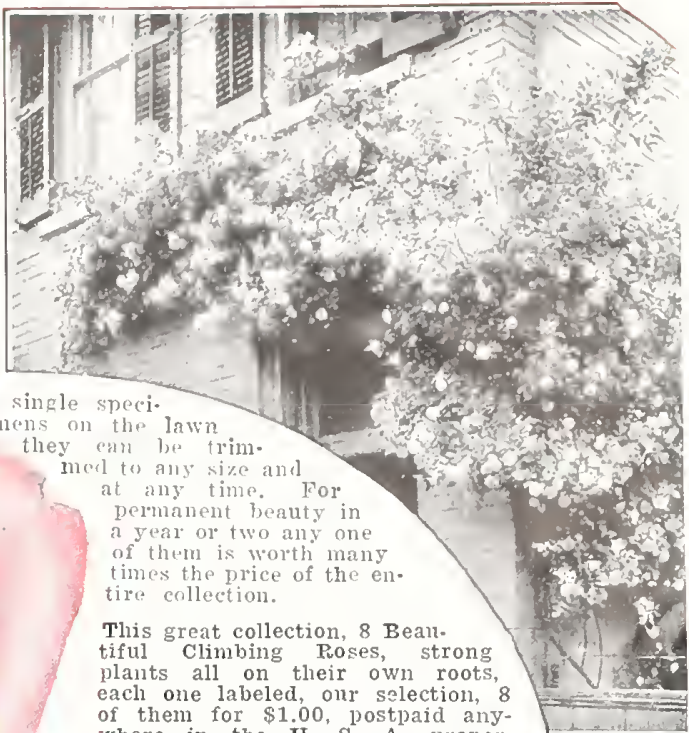

of them for $\$ 1.00$, postpaid any-

PLEASE ORDER AS “THE Climbing Rose FAVORITE COLLECTION

\section{Our Annual Book}

\section{Our beantiful, big anmal book entitled "THE} FOSES OF NEW CASTLE', WII be Sent FREE natiral colors, is the most conplete book on Rose culture ever published. Gives all the in formation you need. Offers and tells how to grow Cannas, Geraninms, Chrysanthemums, Dahlias, coms, Gladiolus and Hardy Shrubs a copy of this great book, ask for it toda yan the supply is exhausted. IT'S FREE!

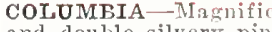

and double silvery pink lowers.

MARIE GUILLOT-A queer among MAD. ABEL CHATENAY-Immen

formed flower

RED RADIANCE- $\mathrm{R}$ i ch crimson:

ALEX HII GRAY-Taroc finely premier white garden Rose. Ahsolute

Special Offer One each, strong plants. 7 garden Roses described above, for \$5.50, by parcel post prepaid with soil on roots.

\section{A Choice Fern Collection}

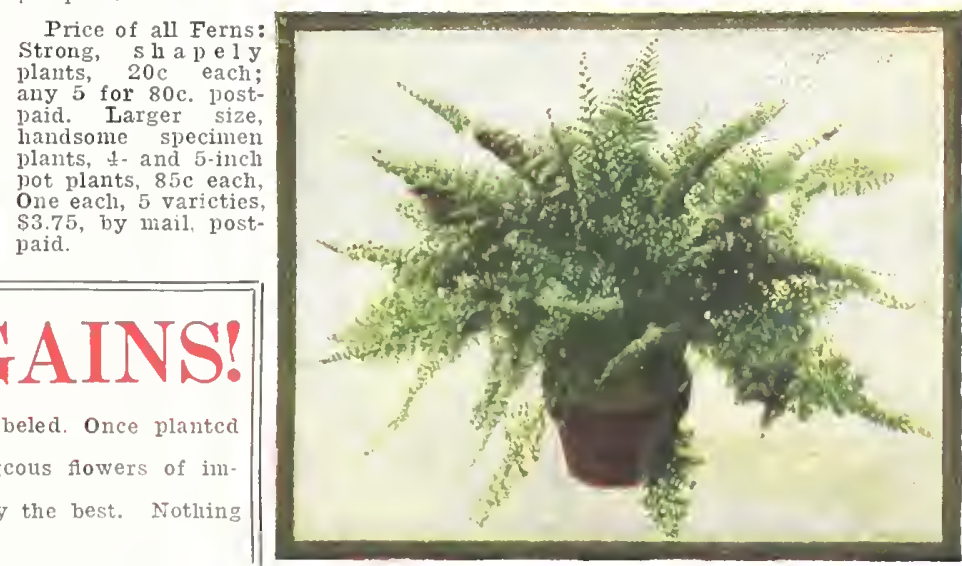




\section{WHAT 50 CENTS WILL BUY}

Greatest Value for the Money Ever Offered

We Send out only the Highest Grade in Every Collection

lowing wonderful low-priced Collections (50 cents each) are made up and offered to

able Roses and other plants listed in our book, "The Roses of New Castle," FREE upon re

Please Order by Collection Number

\section{$5 \mathrm{buys}$ four splen- \\ 30 did new hardy

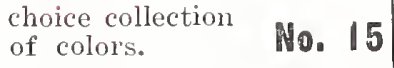

buys 3 hardy

500 Hybrid Tea Ros-

ors and tints
that wo wl please.

(2)

$50 \mathrm{C}$ buys two hardy 2 hardy Climb-

ing Roses. Rare $\mathbf{N}_{\mathbf{0}} \mathbf{1 7}$

\section{C $\begin{aligned} & \text { buys } 3 \text { ehoice } \\ & \text { a n i ums. }\end{aligned}$ Wonderful selec- tion. The col-
or's will please. \\ Mo. 18}

$50 \mathrm{C}$ did four splenrare opportunity

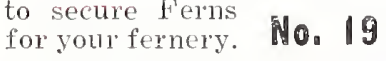
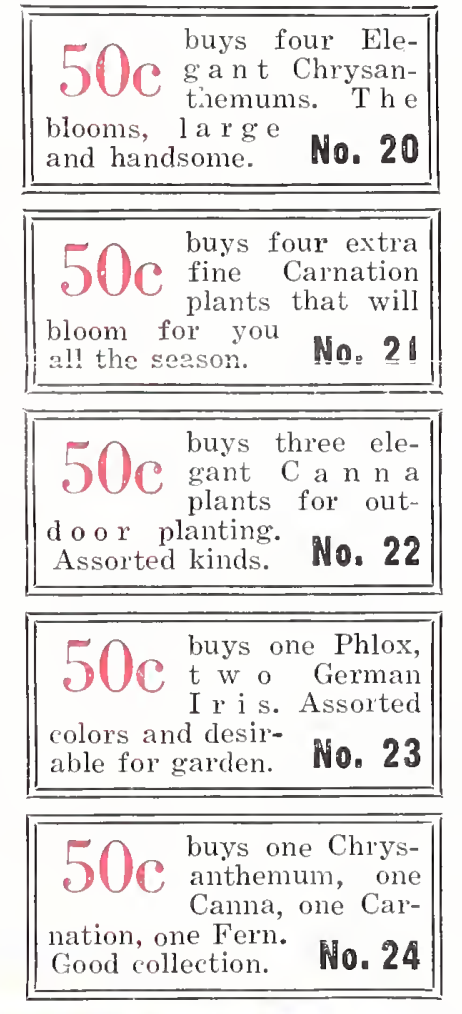

$50 \mathrm{C} \begin{aligned} & \text { buys } 1 \text { Aspara- } \\ & \text { Asparaguseri, } 1\end{aligned}$ mosus, 1 Gera

ium, 1 Fern.

No. 25
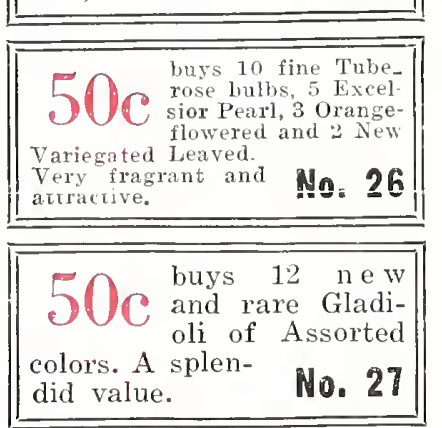

$50 \begin{aligned} & \text { buys three splen- } \\ & \text { did D a h l i a } \\ & \text { bulbs. M i x e d }\end{aligned}$ kinds. Good, hardy tubers.

瓶。. 28

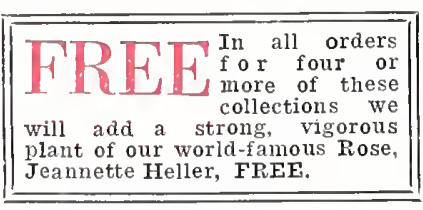

"We now have about thirty Heller Bros. star-size roses and they are a paying invest ment to those growing them for pastine, wher your pronts are measured in lattering compli lost a single plant of yours." -J. E. Wessel, Morrison, Ill.

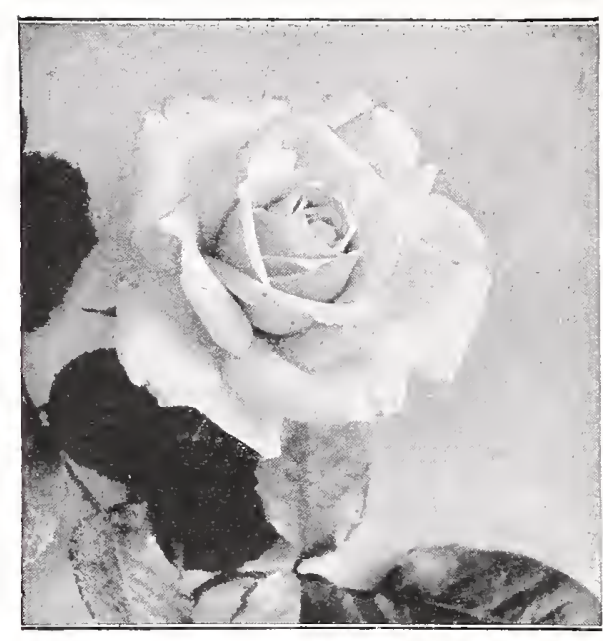

Famous Jeannette Heller Rose

\section{Our Big 'Clean-up' Collection}

\section{2- $\mathrm{Yr}$. Roses for $\$ 6.00$}

we are required to carry an immense Rose stock and rather than carry over two-year-old plants, all high grade Roses in every particular, at a special wholesale price? You are apt to have in tinis collection new and rare Rose novelties, but THE SETECTION IS OURS and plants ARE NOT IABELED. We are selling them below the cost of production. Don't miss this great Bargain offer.

Speciall 0ffer 12 splendid two-yearown roots, from lal'ge pots, finest varieties of Roses in the world, no two alike, not labeled, oUR SELECTION, but including "IMrs. B. P. Cant", the dazzling crimson pink garden Rose; "Jeannette Heller", the one best everblooming Pose in the world, both labeled, and the others equally desirable; soil on the roots, delivered anywhere in the $\boldsymbol{U}$. S. A. safe arrival guaranteed, for $\$ 6.00$, prepaid by parcel post. YOU WILL NEVER HAVR AN OPPORTUNITY TO SECURE ROSF PIANTS, IARGE VIGOROUS GROWAGAIN. BUSHES AT SUCH PRICE:

"T PIEASE ORDER AS THE "CLEANUP COLIECTION."

Planting Instructions These specially prepared pot-grown Rose plants thrive luxuriantly Planting lnstructions in ordinaly good garden soil. Enrich, if possible, with well-rotted manure. Spade deep and plant 15 to 18 incles apart, expose to full sun. The plants come with soil around the roots. Do not disturb it. Plant firmly and fairly deep. Water thoroughly clear to tlie bottom after plariting. Shade the plants with papers for a few ays, if possible, froll
tlie direct rays of the sun, although tlis is not necessary. Do not over-water auring the growing the direct rays of the sun, although this is not necessary. Do not over-water durming the growing
season. Protect these plants during the Winter but do not put the protection on until sever

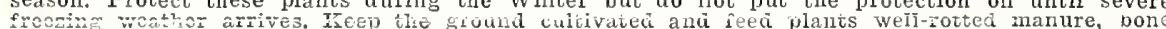
meal or a standard flower food.

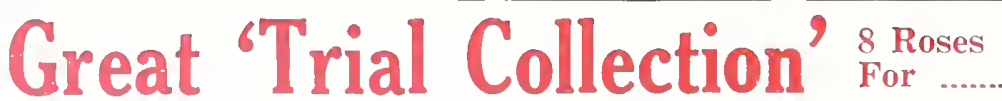

Strong, Hardy Everblooming Rose Plants

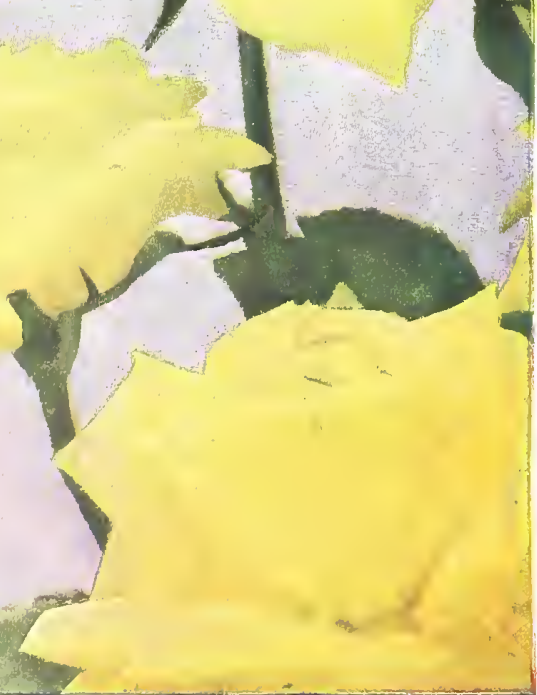

\section{The best value ever offered for the money and the greatest sale of Rose plant} in an history. Neariy a million plants sold in this marvelous collevtion up to datel our list include the finest of the world's productions. All inferior varieties are disfaror through this popular collection. White, pink, red, yellow every tint and shade strong. sturdy plants sure to grow and just as sure to bloom-8 plants in all, each carefuly labeled and packed, sent postpaid anywllere in the 48 states of Americainmense output alone makes this wonderful offer possible. Our selection, sent postImproved Climbing Crimson "Trial Collection" one Excelsa, a sterling novelty-an Ycllow Garden Bush Roses, A. H. Gray, here illustrated. These three Foses alone are PLEASE ORDER AS "TRIAL COLLECTION"

TeNms : CASH WITH ORDER. Personal Check, Postoffice Mozey Order, Bank Draft, Lerns Stanps accepted in small amounts oNIY. 